\title{
Colonization by native species enhances the carbon storage capacity of exotic mangrove monocultures
}

Ziying $\mathrm{He}^{1}$, Huaye Sun ${ }^{2,3}$, Yisheng Peng ${ }^{2,3,4^{*}} \mathbb{D}$, Zhan $\mathrm{Hu}^{1,4^{*}}$, Yingjie $\mathrm{CaO}^{2,3,4}$ and Shing Yip Lee ${ }^{5}$

\begin{abstract}
Background: The fast-growing introduced mangrove Sonneratia apetala is widely used for mangrove afforestation and reforestation in China. Some studies suggested that this exotic species outperforms native species in terms of carbon sequestration potential. This study tested the hypothesis that multi-species mangrove plantations might have higher carbon sequestration potential than S. apetala monocultures.

Results: Our field measurements at Hanjiang River Estuary (Guangdong province, China) showed that the carbon stock ( $46.0 \pm 3.0 \mathrm{Mg} / \mathrm{ha})$ in S. apetala plantations where the native Kandelia obovata formed an understory shrub layer was slightly higher than that in S. apetala monocultures (36.6 $1.3 \mathrm{Mg} / \mathrm{ha})$. Moreover, the carbon stock in monospecific K. obovata stands (106.6 $\pm 1.4 \mathrm{Mg} / \mathrm{ha}$ ) was much larger than that of S. apetala monocultures.

Conclusions: Our results show that K. obovata monocultures may have a higher carbon accumulation rate than $S$. apetala monocultures. Planting $K$. obovata seedlings in existing $S$. apetala plantations may enhance the carbon sink associated with these plantations.
\end{abstract}

Keywords: Mangrove plantation, Carbon storage, Mixed forest, Kandelia obovata, Sonneratia apetala

\section{Background}

Although covering only $0.1 \%$ of Earth's continental surface, mangrove forests are amongst the most carbonrich ecosystems in the world [1, 2]. Mangrove forests differ from terrestrial counterparts in their capacity to store $>90 \%$ of their carbon in the substrate $(5-10.4 \mathrm{Pg}$ globally) over millennial timescales [3-5]. Complex root structures, high sedimentation rates, periodically inundated conditions and muddy anaerobic soils are responsible for exponentially higher carbon burial rates and millesimal lower soil carbon turnover rates in mangroves compared to those of terrestrial forests [6-8]. The high

\footnotetext{
*Correspondence: pyish@mail.sysu.edu.cn; huzh9@mail.sysu.edu.cn ${ }^{1}$ School of Marine Science, Southern Marine Science and Engineering Guangdong Laboratory (Zhuhai), Sun Yat-sen University, Guangzhou 510275, China

2 School of Environmental Science and Engineering, Sun Yat-Sen University, Guangzhou 510275, China

Full list of author information is available at the end of the article
}

carbon sequestration and storage rates are among the mangrove ecosystem services focused including coastal protection, sediment retention, and nurseries for marine fishery species [1, 9-11]. Despite their ecological importance, mangroves are encountering a multitude of anthropogenic threats such as coastal development or pollution, leading to their widespread degradation and decline [12-14]. Mangroves have been significantly deforested during the last several decades in China. The total area of mangrove in China was estimated $\sim 20,303$ ha in 2015, representing less than one-third of the 1950s $[15,16]$. Hence, large investment and great efforts have been paid in mangrove afforestation/reforestation to mitigate the adverse impacts of mangrove loss on biodiversity, ecosystem stability, and carbon sequestration since 1980s in China [16].

The largest carbon pools are associated with living tree biomass and soil organic matter in forest ecosystems 
[17-19]. Thus, carbon stock in these compartments determines the carbon accumulation capacity of mangrove ecosystem. In contrast to terrestrial forests, mangroves allocate a high proportion of their biomass to belowground components, representing more than half of the total standing biomass [20,21]. Carbon stored in belowground biomass varied among mangrove species and more than $50 \%$ of mangroves soil carbon were plantderived [20, 22-25]. The amount of soil organic carbon of mangrove forests dominated by different species varies greatly, from less than $0.5 \%$ to $40 \%$, with a global mean of $2.2 \%[26]$.

Strategies for afforestation have primarily relied on monocultures with low biodiversity, ecological value, and potentially lower capacity for carbon sequestration $[27,28]$. Most countries including China have promoted monocultures in many mangrove reforestation/ afforestation programs by simplistic seedling plantings with dubious long-term survival [29]. Even when successfully established, planting programs often lack adequate cost-benefit and ecosystem services evaluation at the ecosystem level [30]. Sonneratia apetala was native to Bangladesh that introduced to China in 1985 and has been planted extensively in mangrove afforestation programs [31, 32]. In China, the extent of $S$. apetala forests is estimated at $>50 \%$ ( $3800 \mathrm{ha}$ ) of the total mangrove plantations area [24, 33, 34], while Kandelia obovata, a native mangrove species with the widest natural distribution and dominant along the southeast Chinese coastline, has also been widely planted for mangrove afforestation. Ren et al. [33] suggested that the fast-growing S. apetala had great potential on carbon sequestration than most of the native species, and should be preferred in afforestation $[18,33]$. However, the capacity for carbon storage in mangrove ecosystems is species-dependent. Multi-specific plantations have more capacity for carbon sequestration in both biomass and soil, compared to monocultures [27, 35], and are recommended for the implementation of mangrove afforestation programmes. Peng et al. [36] also suggested that native mangrove species can be planted into existing $S$. apetala plantations to establish mixed stands for enhancing functional diversity and provide more 'complete' services than monospecific forests. However, potential differences in the capacity for carbon sequestration between monospecific and multi-specific mangrove plantations are poorly known currently. In the present study, we compared the carbon storage capacity of monocultures of S. apetala (as SA below) and $K$. obovata (as KO below) as well as mixed stands of the two species (as KS below) in Hanjiang River Estuary, southern China. The physiological traits, aboveground biomass, belowground biomass and total carbon storage of the mangrove forests were compared to test the hypotheses that: (1) carbon storage is higher in monospecific $S$. apetala plantations than in monospecific $K$. obovata plantations due to their different growth traits; and (2) the mixed stands stored more carbon in both biomass and soil than the monocultures.

\section{Methods}

Study sites

This study was carried out at Hanjiang River Estuary $\left(23^{\circ} 45^{\prime} \mathrm{N}, 116^{\circ} 43^{\prime} \mathrm{E}\right)$, Guangdong province, China (Fig. 1). The climate in Hanjiang River Estuary is principally influenced by monsoon, with annual precipitation of $1300-1800 \mathrm{~mm}$, and a mean temperature of $21.3^{\circ} \mathrm{C}$. Semi-diurnal tides with a mean range of $1.35 \mathrm{~m}$ occur in the study area. In 2005, monospecific stands respectively of $S$. apetala and $K$. obovata were planted on unvegetated mudflats (as MF below) with an initial density of 2500 seedlings per hectare. After 12 years of development, $K$. obovata $(\mathrm{KO})$ has gradually colonized into $S$. apetala (SA) forests naturally as an understory shrub layer and forming mixed stands with both S. apetala and K. obovata (KS).

\section{Field sampling and laboratory analysis}

In November 2016, we sampled in KO, SA, and the mixed KS forests with nine plots $(10 \mathrm{~m} \times 10 \mathrm{~m})$ in total for aboveground biomass. Tree height, tree density and the stem diameter at breast height $(\mathrm{DBH}$, at $1.3 \mathrm{~m})$ were measured in these plots except for $K$. obovata individuals in plots of KS, due to the infeasibility of measuring DBH because of its shrubby growth form. Tree basal area (BA) was derived from DBH measurements [37]. Species-specific allometric equations were using for calculated the aboveground biomass of $\mathrm{KO}, \mathrm{SA}$, and S. apetala in $\mathrm{KS}$ [32, 38]. For estimating $K$. obovata aboveground biomass in KS, branches and leaves were harvested from three standard trees that randomly selected in each plot. The stem biomass was determined from the product of stem volume and wood density of each sampled tree. Stem volume was measured following the method of Kamal et al. [39] using an Xbox360 Kinect for Windows (Microsoft Inc., USA). The specific stem wood density was determined using stem sections wood samples taken at the base of each sampling tree [40]. The volume of each sample was determined by the water volume displaced when submerged. The specific wood density was calculated as the ratio of oven dried weight $\left(65^{\circ} \mathrm{C}, 72 \mathrm{~h}\right)$ to the volume. The aboveground biomass of $K$. obovata species in KS was calculated by summing the biomass of harvested components and stems.

To determine ground layer biomass, seedlings and litter from five $1 \mathrm{~m} \times 1 \mathrm{~m}$ plots at the three mangrove plantations were collected, then oven dried and weighed. For 


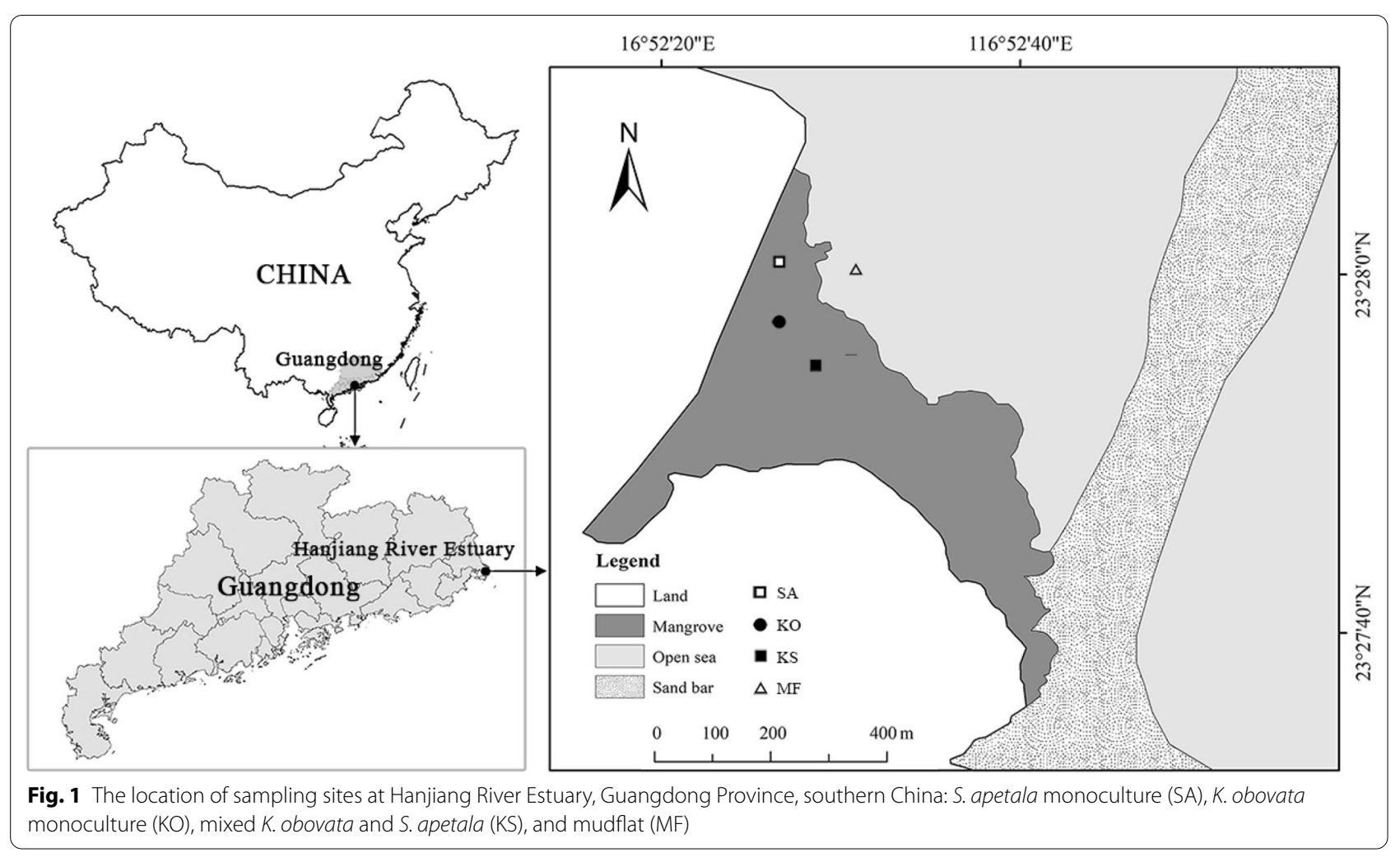

belowground biomass, root coring was conducted at the three mangrove forests. Three standard trees were randomly selected for root coring within each plot. One soil core was taken with a PVC tube of $1 \mathrm{~m}$ in depth at the position of mid-canopy of each tree. In order to minimize the soil compression effect, the PVC tube with a larger diameter $(11 \mathrm{~cm})$ was used. The cores were average divided into five vertical sections. Each root core sample was put on a $0.25 \mathrm{~mm}$ mesh sieve and washed with tap water. Live and dead roots were then separated using $11 \%$ and $6 \%$ colloidal silica solutions (Ludox ${ }^{\circledR}$ TM, Sigma-Aldrich Inc., USA) [41]. All roots samples were then dried at $65{ }^{\circ} \mathrm{C}$ to a constant weight and reweighed. All calculations were based on the dry weights [20,37].

For determination of soil organic carbon content, soil samples were collected by coring at the mangrove forests and the adjacent mudflat. Five cores from each sampling site at the KO, SA plantations and MF (as a control to assess the effect of mangrove afforestation on carbon sequestration), and eight cores at KS were randomly collected. The cores were sectioned to five layers $(0-20$, $20-40,40-60,60-80$ and $80-100 \mathrm{~cm})$. Soil samples were then air-dried for the following laboratory analyses.

Dry biomass samples (leaves, branches, stems, and roots) and soil samples were grounded. Soil samples were processed by the modified Walkley-Black method for determining soil organic carbon content [24, 42, 43].
Biomass samples were analyzed for organic carbon contents using the loss-on-ignition method [24, 44]. The total organic carbon contents of the sample trees were calculated by multiplying the biomass of branches, leaves, flowers, fruits stems and roots by their respective organic carbon contents. The sum of branch, leaf and stem carbon is taken as the aboveground biomass organic carbon. The ground layer biomass organic carbon was estimated by multiplying the dry mass of collected seedlings and litter from each quadrat and their respective organic carbon concentrations. The belowground organic carbon is represented by the root organic carbon storage. The soil organic carbon content in each quadrat was used for estimating soil organic carbon stock of specific layers. The organic carbon stock of soil layers were then summed to estimate the soil organic carbon storage to $1 \mathrm{~m}$ for each sampling site. The total organic carbon storage at each plot was estimated as the sum of the vegetation organic carbon storage, ground layer organic carbon storage, and soil organic carbon storage.

\section{Statistical analysis}

All statistical analyses were performed by SPSS software (version 23.0, SPSS Inc., USA). Significance was determined at $\alpha=0.05$. One-way analysis of variance (ANOVA) was used to test for differences in forest structure, plantation biomass and organic carbon storage 
across forest types. Differences in soil parameters at different depths among the four study sites were also analyzed by one-way ANOVA. Two-way ANOVA was applied to test the difference in soil parameters, root biomass and organic carbon storage in roots and litter among habitats and soil depths. The relationship between organic carbon storage in litter, roots, and soil was explored by linear regression analysis.

\section{Results}

\section{Forest structure and biomass}

Stem density significantly differed among the three mangrove forests $(p<0.001)$. The KO plantation had the highest stand density, while its average stem diameter and height were significantly lower than those of the other two forests $(p<0.001$; Table 1). Natural colonization of $K$. obovata increased the stand density of KS markedly from 1367 to 2600 stem ha ${ }^{-1}$ over the history of forest. Tree height and basal area of S. apetala showed no significant differences between the monoculture and mixed forest, while such parameters of $K$. obovata in the $\mathrm{KO}$ plantation were significantly lower than those of $S$. apetala in both SA and KS.

The highest mean total vegetation biomass occurred in $\mathrm{KO}\left(231.3 \pm 14.7 \mathrm{Mg} \mathrm{ha}^{-1}\right)$, followed by KS and SA at $86.6 \pm 8.2$ and $73.7 \pm 5.4 \mathrm{Mg} \mathrm{ha}^{-1}$, respectively. However, the total vegetation biomass per unit stem of the two forests with $S$. apetala present were both significantly higher than that of $K$. obovata monoculture $(p<0.001$; Table 1). The aboveground and ground layer biomass significantly differed across forest types $(p<0.05$; Table 1$)$, while this profile also applied to total root biomass, which ranged from $3.7 \pm 0.2$ to $34.0 \pm 3.6 \mathrm{Mg} \mathrm{ha}^{-1}(p<0.001$; Table 1). In SA, live root biomass was negatively correlated with soil depth $(p=0.002$; Fig. $2 \mathrm{a})$. Similarly, root necromass in SA significantly decreased with soil depth ( $p=0.003$; Fig. $2 b)$. No significant difference was detected in live root biomass among soil depths in $\mathrm{KO}$, while the root necromass of this species showed a similar distributional pattern in depth as that of SA $(p=0.01$; Fig. 2b). In KS, live root biomass did not differ among soil depths, while root necromass increased with soil depth ( $p<0.001$; Fig. $2 \mathrm{~b})$. The total live root biomass was $1.1 \pm 0.2,17.8 \pm 3.9$ and $3.4 \pm 0.6 \mathrm{Mg} \mathrm{ha}^{-1}$ in SA, KO and KS, respectively, accounting for $29.7 \%, 52.3 \%$ and $28.7 \%$ of total root biomass. There were significant differences between both plantation types and soil depths $(p<0.001)$. Forest types and soil depth also interacted significantly in terms of live root biomass in the three mangrove forests $(p=0.015$; Table 2$)$. The overall root necromass of $\mathrm{KO}$ and KS were $7.3 \pm 1.4$ and $9.5 \pm 1.4 \mathrm{Mg} \mathrm{ha}^{-1}$, respectively, which were significantly higher than that of SA. There were significant differences of root necromass between both forest types and soil depths $(p=0.004$ and 0.008 , respectively; Table 3 ), also with significant interaction effects $(p<0.001$; Table 2).

\section{Organic carbon stocks and accumulation}

The total vegetation organic carbon storage of these three mangrove forests was significantly different, with $\mathrm{KO}\left(85.8 \pm 1.4 \mathrm{MgC} \mathrm{ha}^{-1}\right)$ being 2.5 and 3.0 times higher than those of KS and SA, respectively. The organic carbon storage in aboveground biomass of $\mathrm{KO}$ was significantly higher than those of SA and KS $(p<0.001$; Table 3). Ground layer organic carbon storage accounted for $0.7 \%-4.1 \%$ of the total organic carbon storage, and the ground layer organic carbon storage peaked at KS $(p=0.019$; Table 3$)$. For belowground biomass, the maximum value was $15.8 \pm 0.8 \mathrm{MgC}^{-1}{ }^{-1}$ at $\mathrm{KO}$, which was significantly higher than those of the other two forests

Table 1 Forest structure and biomass of different mangrove forest types in Hanjiang River Estuary

\begin{tabular}{|c|c|c|c|}
\hline \multirow[t]{2}{*}{ Parameters } & \multicolumn{3}{|l|}{ Forest type } \\
\hline & SA & KO & KS \\
\hline Density (stems ha ${ }^{-1}$ ) & $1367 \pm 145^{\mathrm{a \#}}$ & $9533 \pm 63^{\mathrm{c \#}}$ & $2600 \pm 557^{b}$ \\
\hline $\mathrm{DBH}(\mathrm{cm})$ & $14.5 \pm 0.9^{\mathrm{b} \#}$ & $8.8 \pm 0.3^{\text {a\# }}$ & $16.3 \pm 0.9^{b *}$ \\
\hline Tree height (m) & $8.5 \pm 0.3^{\mathrm{b \#}}$ & $4.8 \pm 0.07^{\mathrm{a \#}}$ & $8.8 \pm 0.3^{b *}$ \\
\hline Basal area $\left(\mathrm{m}^{2} \mathrm{ha}^{-1}\right)$ & $26.0 \pm 3.0^{\text {a\# }}$ & $62.7 \pm 4.5^{\mathrm{b \#}}$ & $27.8 \pm 2.8^{\mathrm{a} *}$ \\
\hline Aboveground biomass ( $\mathrm{Mg} \mathrm{ha}^{-1}$ ) & $67.1 \pm 7.7^{\mathrm{a}}$ & $195.8 \pm 23.7^{b}$ & $71.9 \pm 11.7^{a}$ \\
\hline Ground layer biomass (Mg ha-1) & $2.9 \pm 0.6^{b}$ & $1.5 \pm 0.3^{\mathrm{a}}$ & $2.8 \pm 0.5^{b}$ \\
\hline Root biomass (Mg ha ${ }^{-1}$ ) & $3.7 \pm 0.2^{\mathrm{a}}$ & $34.0 \pm 3.6^{c}$ & $11.9 \pm 1.3^{b}$ \\
\hline Total vegetation biomass per unit stem $(\mathrm{kg})$ & $53.9 \pm 3.9^{a}$ & $24.3 \pm 1.5^{c}$ & $33.3 \pm 3.2^{b}$ \\
\hline
\end{tabular}

Data are mean $\pm S E, n=3$ to 5 . Different letters indicate significant differences among the three plantations $(p<0.05)$

Different superscripts in the same column indicate significant difference across forest types $(p<0.05)$

* Data only refers to $S$. apetala species in the mixed KS forest

\# Data source: He et al. [24] 

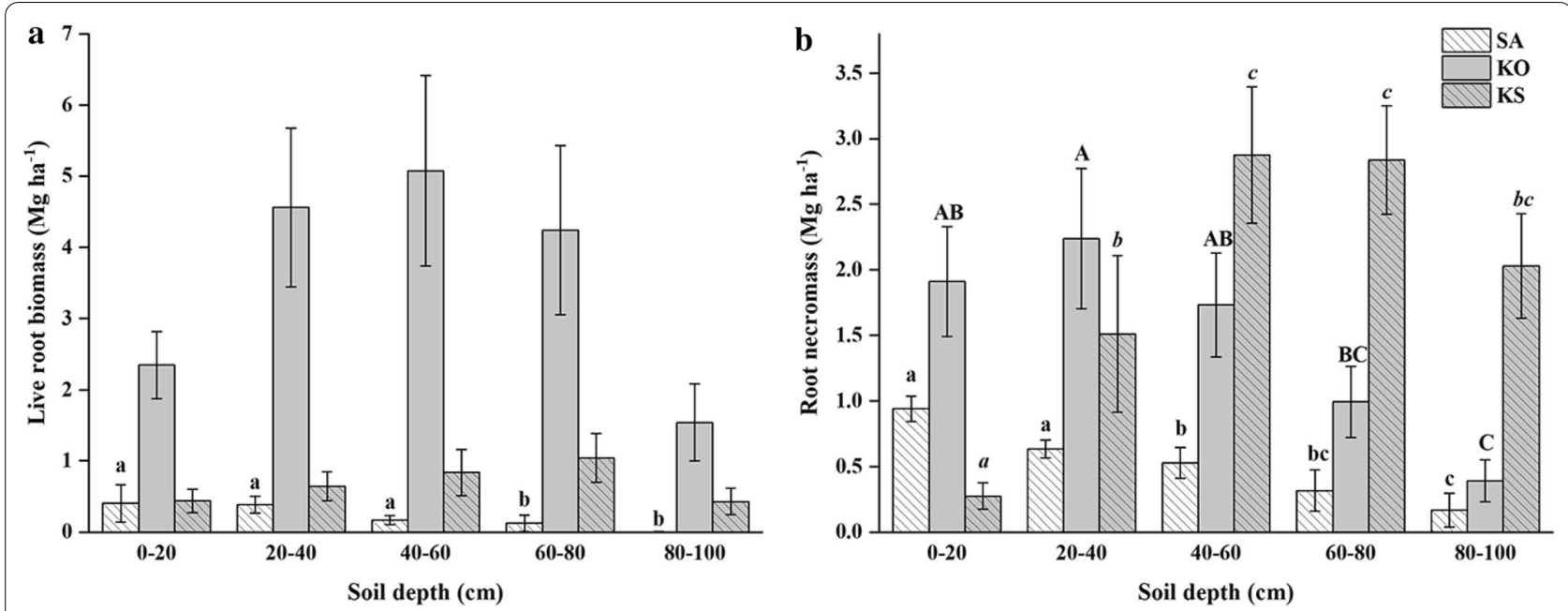

Fig. 2 Vertical distributional patterns of live root biomass (a) and root necromass (b) (mean \pm 1SE) in S. apetala (SA) and K. obovata (KO) monocultures and mixed forest (KS) at Hanjiang River Estuary, south China. Different letters of the same font indicate significant differences among different soil depths within the forest $(p<0.05)$

Table $2 F$ values of two-way ANOVA testing the differences in live roots biomass, roots necromass and soil variables among different mangrove forest types/sites and soil depth in Hanjiang River Estuary, south China

\begin{tabular}{lccc}
\hline Dependent variables & Sources of variance & \\
\cline { 2 - 4 } & Forest types/Sites & Soil depth & $\begin{array}{c}\text { Forest types/ } \\
\text { Sites } \times \text { Soil } \\
\text { depth }\end{array}$ \\
\hline Live roots biomass $\left(\mathrm{Mg} \mathrm{ha}^{-1}\right)$ & $33.454^{* *}$ & $5.058^{* *}$ & $7.429^{*}$ \\
Root necromass $\left(\mathrm{Mg} \mathrm{ha}^{-1}\right)$ & $5.127^{*}$ & $4.162^{*}$ & $0.738^{* *}$ \\
Organic carbon storage in live roots $\left(\mathrm{MgC} \mathrm{ha}^{-1}\right)$ & $34.316^{*}$ & $5.812^{* *}$ & $2.804^{* *}$ \\
Organic carbon storage in dead roots $\left(\mathrm{MgC} \mathrm{ha}^{-1}\right)$ & $15.063^{* *}$ & 2.227 & $5.162^{* *}$ \\
Organic carbon storage in soil $\left(\mathrm{MgC} \mathrm{ha}^{-1}\right)$ & $2.659^{*}$ & $34.167^{* *}$ & $6.629^{* *}$ \\
\hline
\end{tabular}

${ }^{*} p<0.05(\mathrm{n}=75$ to 85$) ;{ }^{* *} p<0.001(\mathrm{n}=75$ to 85$)$

Table 3 Organic carbon storage in different component of different habitats in Hanjiang River Estuary

\begin{tabular}{|c|c|c|c|c|}
\hline \multirow[t]{2}{*}{ Parameters } & \multicolumn{4}{|l|}{ Habitats } \\
\hline & SA & KO & KS & MF \\
\hline $\mathrm{AGOC}(\mathrm{MgC} \mathrm{ha}-1)$ & $26.1 \pm 0.8^{b}$ & $73.6 \pm 1.3^{\mathrm{a}}$ & $27.3 \pm 0.7^{b}$ & NA \\
\hline $\mathrm{BGOC}\left(\mathrm{MgC} \mathrm{ha}^{-1}\right)$ & $1.2 \pm 0.1^{c}$ & $11.5 \pm 1.0^{\mathrm{a}}$ & $5.2 \pm 0.5^{b}$ & NA \\
\hline AGOC:BGOC & $21.9^{\mathrm{a}}$ & $6.4^{b}$ & $5.3^{c}$ & NA \\
\hline GLOC $\left(\mathrm{MgC} \mathrm{ha}^{-1}\right)$ & $1.5 \pm 0.3^{\mathrm{a}}$ & $0.7 \pm 0.1^{b}$ & $1.6 \pm 0.2^{\mathrm{a}}$ & NA \\
\hline $\mathrm{SOC}\left(\mathrm{MgC} \mathrm{ha}^{-1}\right)$ & $7.8 \pm 0.5^{\mathrm{c \#}}$ & $15.8 \pm 0.8^{\text {a\# }}$ & $11.9 \pm 2.4^{b}$ & $4.7 \pm 0.9^{\mathrm{d} \#}$ \\
\hline $\mathrm{TOC}\left(\mathrm{MgC} \mathrm{ha} \mathrm{C}^{-1}\right)$ & $36.6 \pm 1.3^{c}$ & $101.6 \pm 1.4^{\mathrm{a}}$ & $46.0 \pm 3.0^{b}$ & $4.7 \pm 0.9^{d}$ \\
\hline $\begin{array}{l}\text { TOC per unit stem } \\
(\mathrm{kgOC})\end{array}$ & $26.8 \pm 8.9^{a}$ & $10.7 \pm 2.2^{c}$ & $17.7 \pm 5.4^{b}$ & NA \\
\hline
\end{tabular}

Data are mean $\pm \mathrm{SE}, \mathrm{n}=3$ to 5

Superscripts in the same column indicate significant difference across forest types $(p<0.05)$. AGOC, BGOC, GLOC, SOC and TOC refer to aboveground,

belowground, ground layer, soil, and total organic carbon storage, respectively

\# Data source: He et al. [24] $(p<0.001$; Table 3$)$. Ratios of organic carbon storage in aboveground to belowground biomass may provide an indication of the proportion of $\mathrm{C}$ allocated to above- and belowground components. These ratios were 21.9 in $\mathrm{SA}, 6.4$ in $\mathrm{KO}$ and 5.3 in KS, and were significantly different. Organic carbon storage in live roots varied with depth and the mean values were $0.3 \pm 0.06,6.7 \pm 0.8$ and $1.3 \pm 0.2 \mathrm{MgC} \mathrm{ha}^{-1}$ in SA, KO and KS, respectively (Fig. 3). Significant differences in live root organic carbon storage among the three forest types and soil depths were detected $(p<0.001$; Table 2). In SA and KO, the organic carbon storage in dead roots significantly decreased with soil depth $(p=0.002$ or 0.009 ; Fig. 3a, b). In contrast, organic carbon storage in dead roots in KS increased with soil depth $(p<0.001$; Fig. $3 c)$. Organic carbon storage in live and dead roots of $\mathrm{KO}$ was significantly higher than those of SA and KS ( $p<0.001$; Table 2). Plantation type and soil depth have significant interactive effects on 

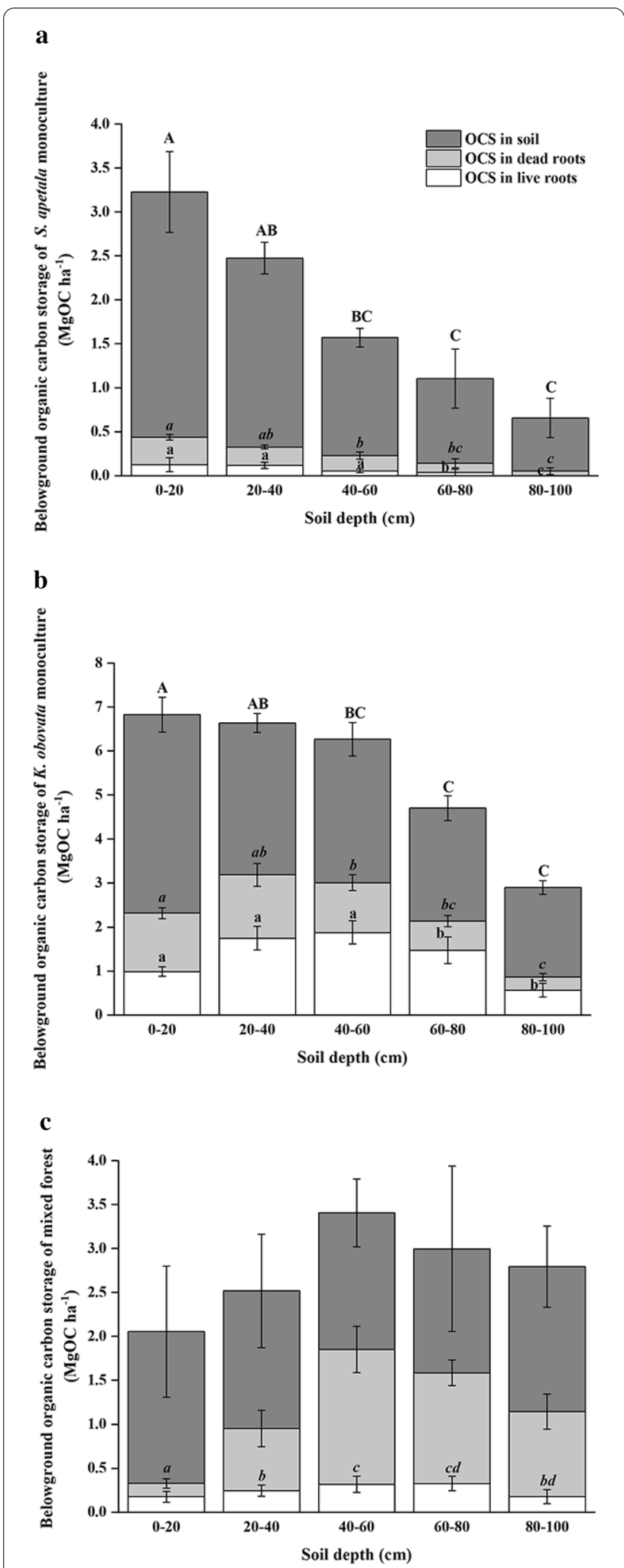

Fig. 3 Belowground organic carbon storage of S. apetala (a), $K$. obovata (b) monocultures and mixed forest (c) (mean $\pm 1 \mathrm{SE}$ ) at Hanjiang River Estuary, south China. Different letters in of the same front indicated significant differences among the different soil depths $(p<0.05)$. OCS refers to organic carbon storage organic carbon storage in live and dead roots of the three mangrove plantations $(p<0.01$; Table 2$)$.

The mangrove forests $(0.96-3.3 \%)$ showed significantly higher soil organic carbon concentration than the mudflat $(0.55 \%) 12$ years after the mangrove planted and subsequent forest growth. The soil organic carbon $(\mathrm{SOC})$ concentration $(0-100 \mathrm{~cm})$ of the mangrove forests varied between $0.96 \pm 0.3 \%$ (He et al. [24] at SA and $3.3 \pm 0.4 \%$ (He et al. [24] at $\mathrm{KO}$, with the SOC concentration of both $\mathrm{KO}$ and $\mathrm{KS}(2.1 \pm 0.4 \%)$ being significantly higher than that of SA $(p<0.001)$. The SOC concentration significantly decreased with soil depth for $\mathrm{KO}$ and SA but no significant trend was evident for KS and MF. Soil bulk density (SBD) showed the opposite trend to SOC concentration. The adjacent unvegetated mudflat had the highest SBD value for the entire $1 \mathrm{~m}$ soil column $\left(0.94 \pm 0.08 \mathrm{~g} \mathrm{~cm}^{-3}\right.$; He et al. [24]) among the four study sites, which was close to that of SA $\left(0.89 \pm 0.04 \mathrm{~g} \mathrm{~cm}^{-3}\right.$; He et al. [24]). The mean SBD $(0-100 \mathrm{~cm})$ of $\mathrm{KO}\left(0.45 \pm 0.03 \mathrm{~g} \mathrm{~cm}^{-3}\right.$; He et al. [24] and KS $\left(0.64 \pm 0.05 \mathrm{~g} \mathrm{~cm}^{-3}\right)$ were significantly lower than those of MF and SA $(p<0.001)$, indicating much finer sediment was found in these forests. The mean organic carbon storage in soil of $\mathrm{KO}$ was $15.8 \pm 0.8 \mathrm{MgC} \mathrm{ha}^{-1}$, $2.01,1.33$ and 3.35 times higher than those of SA, KS and MF, respectively. Soil organic carbon storage was also significantly affected by site and soil depth, with a significant interaction effect ( $p<0.01$; Tables 2 and 3 and Fig. 3 ).

The total organic carbon storage of different habitats was estimated by summing the vegetation organic carbon storage, ground layer organic carbon storage, and soil organic carbon storage. In general, total organic carbon storage was highest in $\mathrm{KO}$ amongst all habitats, then decreasing significantly in the order KS, SA and MF $(p<0.001$; Table 3$)$. However, this trend was reversed in the individual tree level (Table 3 ).

\section{Organic carbon allocation patterns in different forests}

Total organic carbon storage in all mangrove forests was positively correlated with organic carbon storage in aboveground biomass, belowground biomass, and soil $(p<0.05$; Fig. 4). Moreover, in SA and KS, a significant positive correlation was found between organic carbon storage in litter and total organic carbon storage, while no such relationship was detected in $\mathrm{KO}$, suggesting that roots contributed mostly to forest total organic carbon stock in $\mathrm{KO}(p<0.01$; Fig. 4$)$.

Due to their vital contribution to soil organic carbon storage, the correlation among litter, root and soil organic carbon had also explored. The highest value of organic carbon storage in litter was found in $\mathrm{KS}\left(0.6 \pm 0.07 \mathrm{MgC} \mathrm{ha}^{-1}\right)$ and the lowest in $\mathrm{KO}\left(0.15 \pm 0.08 \mathrm{MgC} \mathrm{ha}^{-1}\right)$. Soil organic carbon density in all forests was significantly positively 

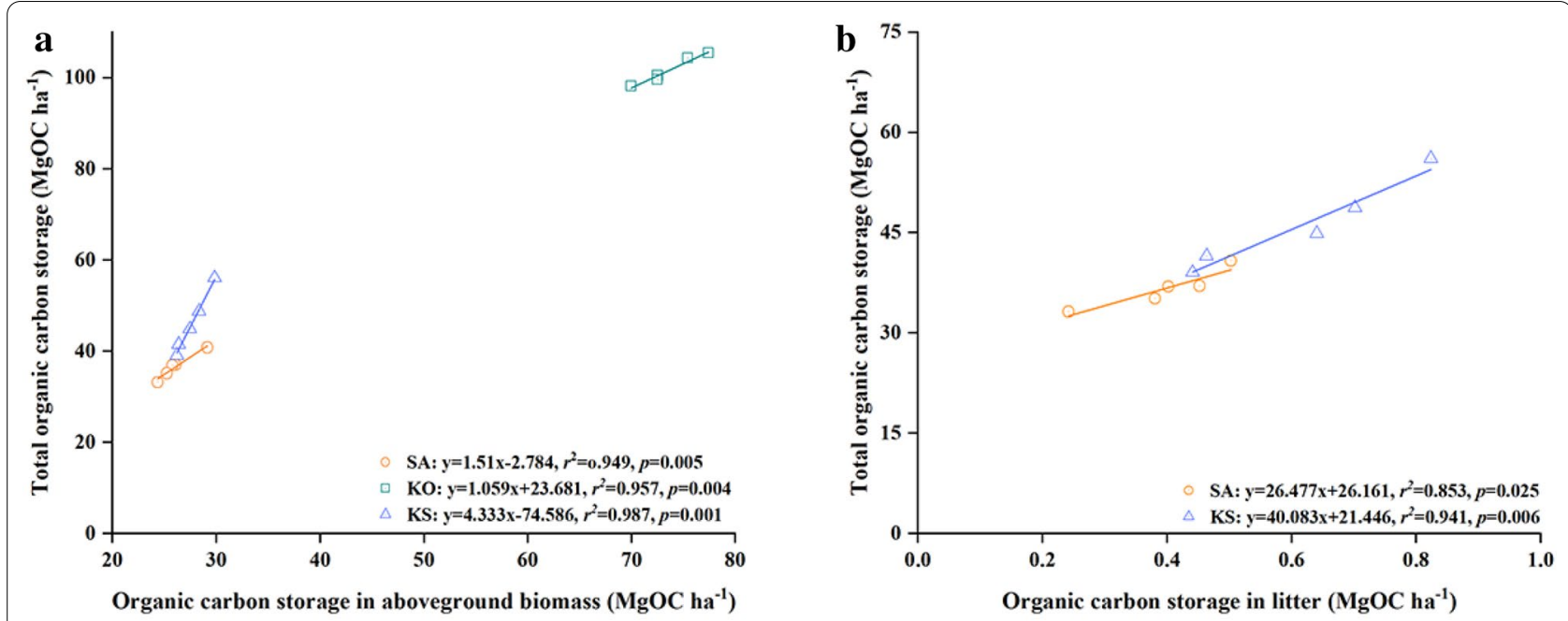

c

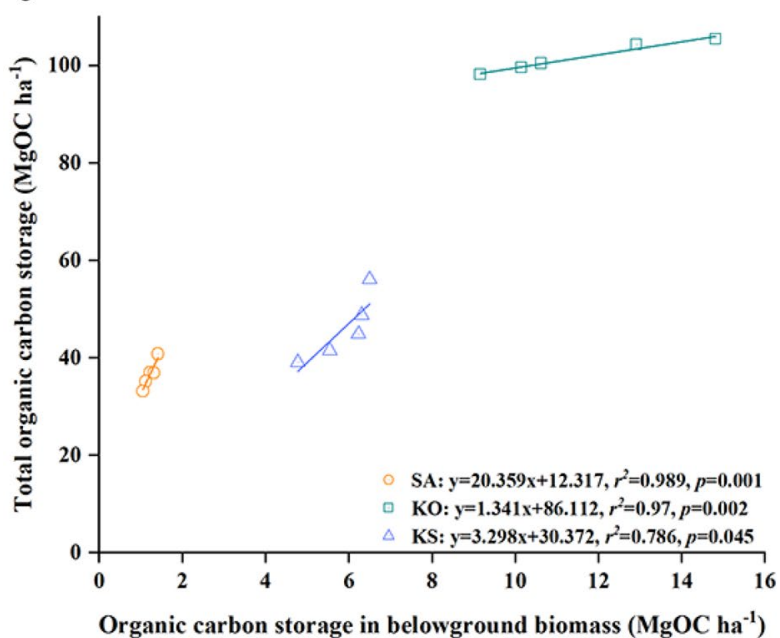

d

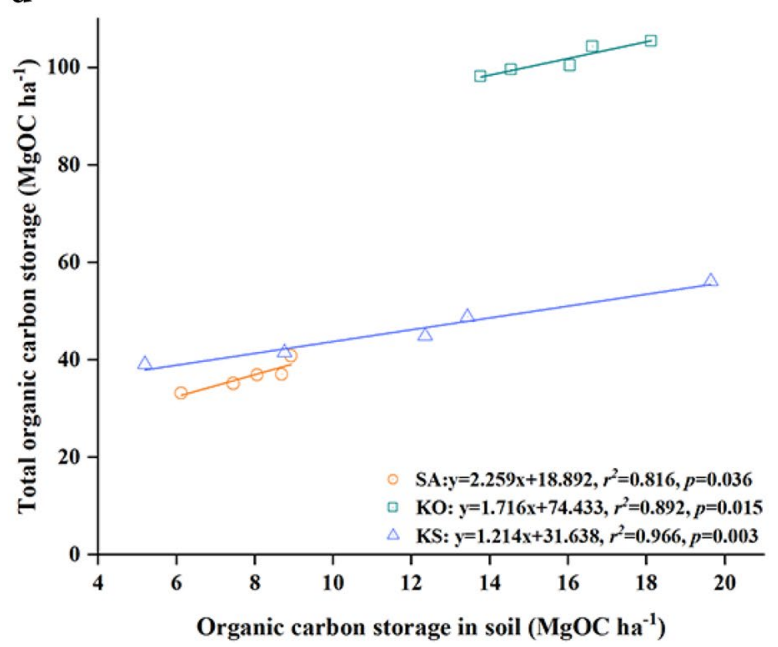

Fig. 4 Regression analysis between total organic carbon storage and organic carbon storage in different components in the three mangrove forests in Hanjiang River Estuary, south China

correlated to organic carbon storage in litter, and the slope of the regression line of SA and KS were significantly steeper than that of $\mathrm{KO}(p<0.01$; Fig. 5). Similarly, in all forests, a significant positive correlation was detected between organic carbon storage in soil and roots. The slopes of the regression lines are all significantly different, suggesting that the contribution of root organic carbon to soil organic carbon is dependent on stand composition $(p<0.001$; Fig. 5).

\section{Discussion}

\section{Organic carbon accumulation varies with different mangrove species}

In most terrestrial forests, the largest carbon pools are associated with aboveground biomass and soil organic matter, with lesser contributions from roots and ground layer detritus [17]. Fast-growing species accumulate more carbon than slow-growing ones [45], which is consistent with our result that the individual biomass organic carbon stock in S. apetala monoculture was significantly higher than that of $K$. obovata monoculture. However, due to the characteristics of fast growth and intolerance to canopy shade of $S$. apetala, intense selfthinning occurs to result in lower tree density in the SA monoculture [32]. This development pattern explains the significant lower total biomass organic carbon stock of SA compared to $\mathrm{KO}$ at the forest level, despite the larger individual tree size in the former species.

The mixed forest of K. obovata and S. apetala (KS) has intermediate organic carbon biomass levels compared with the $\mathrm{KO}$ and SA monocultures. Colonization by $K$. obovata in the understory enhances the organic 

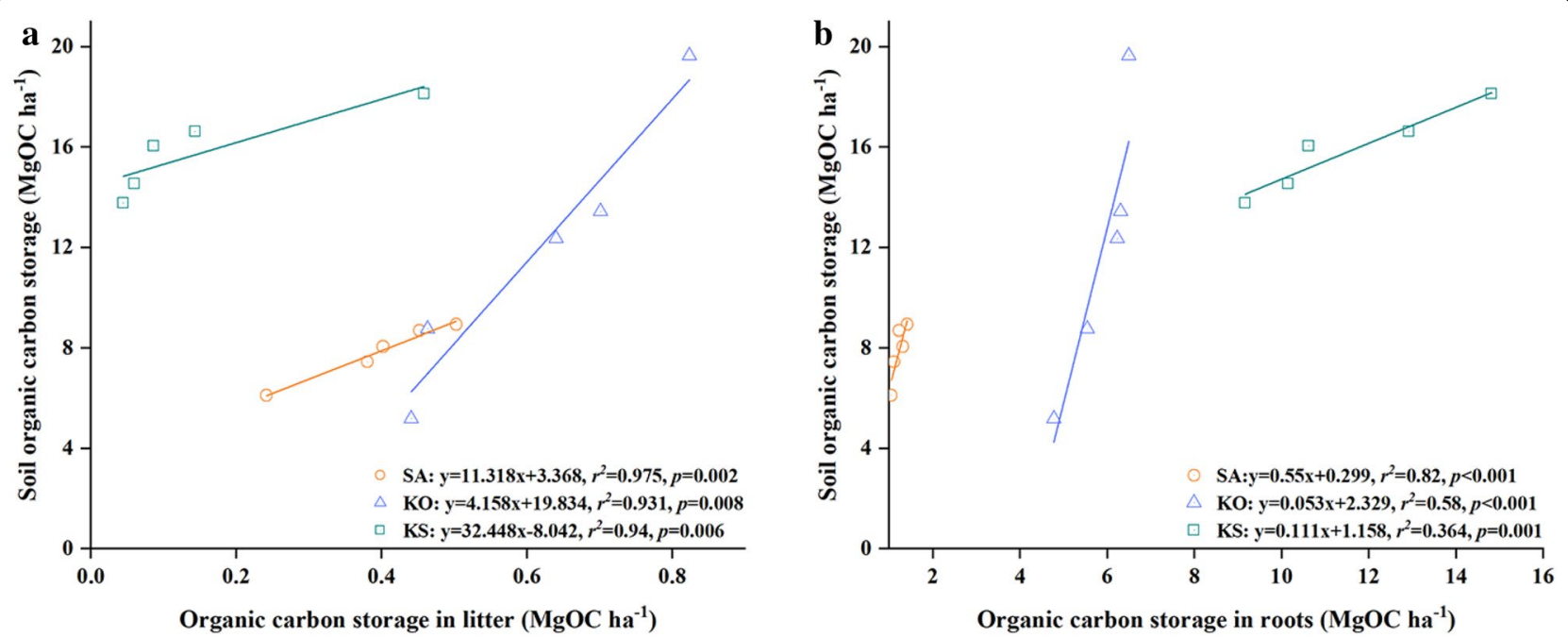

Fig. 5 Regression analyses between soil organic carbon storage and organic carbon storage in litter and roots in the three mangrove forests in Hanjiang River Estuary, south China

carbon storage in the $S$. apetala dominated plantation. In KS, growth of $S$. apetala individuals as reflected by tree height and basal stem diameter was not significantly different with those in SA. When the native $K$. obovata recruited naturally into the $S$. apetala plantation, the faster-growing $S$. apetala occupied the higher spatial niche, whereas $K$. obovata formed a lower shrub layer, indicating the native $K$. obovata is more shadetolerant than the exotic and fast-growing $S$. apetala [46]. Despite the spread and colonisation of $K$. obovata significantly increased the stem density of KS, organic carbon storage in aboveground and ground layer biomass of KS was not significantly different from the SA monoculture. The difference in biomass organic carbon storage between KS and SA can be attributed to different root biomass between the two forests. In the monocultures, both root biomass and root organic carbon stock of $S$. apetala individuals were significantly higher than those of $K$. obovata. However, when the effect of density is considered, such pattern is reversed, i.e. SA supported significantly lower root biomass and organic carbon stock than KO did. Further, live root biomass and root necromass in SA decreased with soil depth. This might reflect the faster decomposition rates of $S$. apetala roots compared with those of $K$. obovata [20, 47].

Sonneratia apetala had significantly higher live root biomass, root necromass and root organic carbon storage in the mix forest (KS) than in the SA monoculture. The colonisation of $K$. obovata is associated with a different profile in root growth in S. apetala, which allowed the complementary vertical niche differentiation in belowground space utilisation in this mixed-species zone. The taller S. apetala was characterized with deeper root system in soil, while the shorter $K$. obovata occupied the understory of forest and developed shallower roots in soil. Positive interactions in mixed species forests may increase productivity beyond that of monospecific stands [48]. Our findings suggest different interaction outcomes, i.e. positive and negative effects on individual biomass, respectively, for $S$. apetala and $K$. obovata, in the mixed forest [48]. A 25-month experiment showed that a mixed stand of $S$. apetala and $S$. caseolaris had lower carbon storage in biomass than in the monocultures due to the interspecific competition for light [23]. Similar consequences seem to apply to K. obovata, the growth of which was impeded by the relative low light condition under the $S$. apetala canopy.

\section{Organic carbon accumulation in soil}

It should be noted that the soil organic carbon detected in our study was lower than previously reported in mangroves. The difference might be due to the original soil substrate, spatial climatic conditions or the age of trees. Soil organic matter comprises the largest $\mathrm{C}$ pool in most forests [17]. Soil organic carbon storage represented $58 \%-87 \%$ of the belowground organic carbon storage and contributed the majority of the forest carbon pool in this study. On average, 58\% of mangrove soil carbon is derived from litter and root production, which is the major transfer pathway for plant tissue carbon into soil [22, 26, 49, 50]. A significant positive correlation exists between the organic carbon storage in litter and soil in 
all three mangrove forests. However, SA produced more organic carbon in litter than $\mathrm{KO}$ did, while a reversed pattern applies to the soil organic carbon stocks. The organic carbon in roots of the three mangrove forests varied not only with depth but also across mangrove species. Significant positive correlations between organic carbon in roots and soil was also present for all forest types, suggesting that roots may contribute significantly to soil organic carbon accumulation. Roots have a more significant effect than litter on soil composition and vertical soil accretion in mangrove forests $[22,51]$.

Effects of mangrove species on soil organic matter accumulation depends primarily on their strategies of root production [50]. The soil bulk density in the mangrove forests was lower than that of the adjacent unvegetated mudflat. Compared with KS and SA where S. apetala was present, the greater roots biomass and soil organic carbon stock of monospecific $\mathrm{KO}$ had a lower soil bulk density. The development of mangrove roots and soil organic matter accumulation process may result in a more porous and less compacted substrate. The root system including pneumatophores of S. apetala may facilitate deposition of organic matter on the tidal flat adjacent to the forest fringe. The lack of pneumatophores may require $K$. obovata to develop more superficial fine roots to enhance gas exchange and nutrient uptake in the anoxic soils. These may facilitate sedimentation and promote soil organic carbon accumulation in the surface soil $[23,52]$.

The colonisation of $K$. obovata not only diversified the spatial niche utilisation of the forest, but also increased the overall root biomass of the $S$. apetala forests. Notwithstanding, colonisation comes with a cost to $K$. obovata: the low light condition resulted in reduced root production of this species in mixed forests compared to the $\mathrm{KO}$ monoculture. For belowground carbon accumulation, the rate of root production must exceed that of carbon loss [53]. Root decomposition rate is also a key factor to soil organic carbon accumulation, which is primarily driven by soil characteristic, rainfall, tidal regime and mangrove forest types [47, 54-56]. The large amount of undecomposed root necromass from $K$. obovata reduces the overall root decomposition rate of the mixed forest and may contribute to the higher organic matter accumulation than in the S. apetala monoculture. Increased root productivity coupled with reduced decomposition in anoxic soils is a dominant driver in carbon sequestration by mangrove forests [20].

\section{The potential for maximising carbon storage} through multi-specific mangrove plantations

Large-scale monospecific plantations of selected species based on growth rate (e.g. Sonneratia spp.) or ease of planting (e.g. Rhizophora spp.) have dominated the global strategy for mangrove restoration [29]. However, natural colonisation of non-planted species into mangrove monocultures can increase their productivity substantially [57]. Coexistence might also change the carbon allocation strategy of afforested species compared to monospecific plantations [58]. Although our study demonstrates that multi-canopy forests may not necessarily have higher carbon storage than monospecific stands because of interspecific competition, there is potential for managing the interactions to achieve optimal outcomes. Lowering the density of S. apetala in the mixed forest may alleviate adverse competition effects on K. obovata, achievable through a proper density matching process during the early stage of afforestation $[59,60]$. There is much room for developing the necessary knowledge as well as its application of multispecies mangrove restoration as a central strategy in mangrove restoration.

In China, more than $80 \%$ of the mangrove plantations after 2000 are dominated by S. apetala [33]. In southern China, S. apetala has naturalised at over $40 \%$ of the original natural mangrove forests [46]. As demonstrated by our study, the large extent of S. apetala monocultures presents great opportunities to improve their ecological services such as carbon storage potential by transforming them into multi-specific forests through introduction of native species with complementary niches.

\section{Conclusion}

Contrary to the hypothese inferred from aboveground morphology and individual appearances of mangrove species, the overall root biomass and organic carbon storage in the $K$. obovata monoculture were significantly higher than those of both the $S$. apetala monoculture and mixed forest, suggesting that $K$. obovata should be preferred to $S$. apetala for mangrove afforestation programs in the future. Improved spatial niche utilization through the colonization by $K$. obovata in $S$. apetala monocultures promoted organic carbon storage both in biomass and soil. The increase in stem density was a principle factor that the multi-canopy forest supported higher productivity and carbon storage than the monospecific pure stands. Root production and decomposition contributed more than litter dynamics on soil organic carbon accumulation, driving species-specific as well as overall rates of soil organic matter accumulation. For the existing mono-specific plantations, especially for $S$. apetala forests, introducing native mangroves may enhance their carbon storage capacity for a long-term perspective. 


\section{Abbreviations}

AGB: Above ground biomass; AGOC: Above ground organic carbon; ANOVA: Analysis of variance; BA: Basal area; BGB: Below ground biomass; BGOC: Below ground organic carbon; DBH: Diameter of breast height; $G L$ : Ground layer; GLOC: Ground layer organic carbon; NA: Not applicable; NS: Not significant; SBD: Soil bulk density; SE: Standard error; SOC: Soil organic carbon; SPSS: Statistical Product and Service Solutions; TOC: Total organic carbon.

\section{Acknowledgements}

In memory of Ms. Guizhu CHEN (1944-2020) who devoted her entire caree to the conservation, restoration, and utilization of mangrove ecosystems, the authors would like to contribute this work for her endeavour, persistence, and wisdom of the last forty years. The authors sincerely acknowledge Siluo Chen and Zhushi Yin for field assistance, and Zhixiong Chen, Liqing Guo and Qingjuan Fan for assistance with laboratory instruments. Prof. Renduo Zhang from Sun Yat-Sen University is gratefully thanked for his valuable comments and suggestions on the earlier version of this manuscript.

\section{Authors' contributions}

$\mathrm{ZH}$ contributed to the research idea, experimental design, field work, data analysis and the final drafts of the manuscript; HS contributed to field work, laboratory work and produced Fig. 1; YP contributed to the research idea, experimental design, and field work, and improved the earlier version of the manuscript; ZH contributed to the experimental design, and preparation of the manuscript; $Y C$ contributed to the research idea and experimental design; SL contributed to the research idea, experimental design, data analysis, and improved the earlier version of the manuscript. All authors read and approved the final manuscript.

\section{Funding}

This study was financially supported by National Nature Science Foundation Grants of China $(41771095,51761135022,41371109)$, Natural Science Foundation of Guangdong Province, China (2017A030313231), Guangdong Provincial Department of Science and Technology (2019ZT08G090), and China Postdoctoral Science Foundation funded project (2020M672939).

\section{Availability of data and materials}

The data supporting this project are clearly referenced or available in this paper itself. The data used to produce the figures in this paper can be provided as request.

\section{Ethics approval and consent to participate}

Not applicable.

\section{Consent for publication}

Not applicable.

\section{Competing interest}

The authors declare no conflict of interest.

\section{Author details}

${ }^{1}$ School of Marine Science, Southern Marine Science and Engineering Guangdong Laboratory (Zhuhai), Sun Yat-sen University, Guangzhou 510275, China. ${ }^{2}$ School of Environmental Science and Engineering, Sun Yat-Sen University, Guangzhou 510275, China. ${ }^{3}$ Guangdong Provincial Key Laboratory of Environmental Pollution Control and Remediation Technology, Sun Yat-Sen University, Guangzhou 510275, China. ${ }^{4}$ Southern Marine Science and Engineering Guangdong Laboratory, Sun Yat-Sen University, Zhuhai 519000, China. ${ }^{5}$ Simon F. S. Li Marine Science Laboratory, School of Life Sciences, The Chinese University of Hong Kong, Hong Kong SAR, China.

Received: 5 January 2020 Accepted: 4 December 2020 Published online: 14 December 2020

\section{References}

1. Bouillon S, Borges AV, Castañeda-Moya E, Diele K, Dittmar T, Duke NC, Kristensen E, Lee SY, Marchand C, Middelburg JJ, Rivera-Monroy VH, Smith TJ III, Twilley RR. Mangrove production and carbon sinks: a revision of global budget estimates. Global Biogeochem CY. 2008;22:1-12.
2. Donato DC, Kauffman JB, Murdiyarso D, Kurnianto S, Stidham M, Kanninen M. Mangroves among the most carbon-rich forests in the tropics. Nat Geosci. 2011:4:293.

3. Duarte CM, Losada IJ, Hendriks IE, Mazarrasa I, Marbà N. The role of coastal plant communities for climate change mitigation and adaptation. Nat Clim Change. 2013;3:961.

4. Jardine SL, Siikamäki JV. A global predictive model of carbon in mangrove soils. Environ Res Lett. 2014;9:00104013.

5. Marchand C. Soil carbon stocks and burial rates along a mangrove forest chronosequence (French Guiana). Forest Ecol Manag. 2017;384:92-9.

6. Alongi DM. Carbon sequestration in mangrove forests. Carbon Manag. 2012;3:313-22.

7. Atwood TB, Connolly RM, Almahasheer H, Carnell PE, Duarte CM, Ewers Lewis CJ, Irigoien X, Kelleway JJ, Lavery P, Macreadie PI, Serrano O, Sanders CJ, Santos I, Steven ADL, Lovelock CE. Global patterns in mangrove soil carbon stocks and losses. Nat Clim Change. 2017;7:523.

8. Mcleod E, Chmura GL, Bouillon S, Salm R, Björk M, Duarte CM, Lovelock CE, Schlesinger WH, Silliman BR. A blueprint for blue carbon: toward an improved understanding of the role of vegetated coastal habitats in sequestering $\mathrm{CO}_{2}$. Front Ecol Environ. 2011;9:552-60.

9. Giri C, Ochieng E, Tieszen LL, Zhu Z, Singh A, Loveland T, Masek J, Duke N. Status and distribution of mangrove forests of the world using earth observation satellite data. Global Ecol Biogeogr. 2011;20:154-9.

10. Lee SY, Primavera JH, Dahdouh-Geubas F, McKee K, Bosire JO. Ecological role and services of tropical mangrove ecosystems: a reassessment. Global Ecol Biogeog. 2014;23:726-43.

11. Stringer CE, Trettin CC, Zarnoch SJ, Tang W. Carbon stocks of mangroves within the Zambezi River Delta Mozambique. Forest Ecol Manag. 2015;354:139-48.

12. Alongi DM. Present state and future of the world's mangrove forests. Environ Conserv. 2002:29:331-49.

13. Hamilton SE, Casey D. Creation of a high spatio-temporal resolution global database of continuous mangrove forest cover for the 21 st century (CGMFC-21). Global Ecol Biogeogr. 2016;25:729-38.

14. Lovelock CE, Cahoon DR, Friess DA, Guntenspergen GR, Krauss KW, Reef R, Rogers K, Saunders ML, Sidik F, Swales A, Saintilan N, Thuyen LX, Triet T. The vulnerability of Indo-Pacific mangrove forests to sea-level rise. Nature. 2015;526:559-63.

15. Chen B, Xiao X, Li X, Pan L, Doughty R, Ma J, Dong J, Qin Y, Zhao B, Wu Z, Sun R, Lan G, Xie G, Clinton N, Giri C. A mangrove forest map of China in 2015: analysis of time series Landsat 7/8 and Sentinel-1A imagery in Google Earth Engine cloud computing platform. ISPRS J Photogramm. 2017;131:104-20.

16. Li M, Lee SY. Mangroves of China: a brief review. Forest Ecol Manag. 1997;96:241-59.

17. Fahey TJ, Woodbury PB, Battles JJ, Goodale CL, Hamburg SP, Ollinger SV, Woodall CW. Forest carbon storage: ecology, management, and policy. Front Ecol Environ. 2010:8:245-52.

18. Liu H, Ren H, Hui D, Wang W, Liao B, Cao Q. Carbon stocks and potential carbon storage in the mangrove forests of China. J Environ Manage. 2014;133:86-93.

19. Sharma CM, Baduni NP, Gairola S, Ghildiyal SK, Suyal S. Tree diversity and carbon stocks of some major forest types of Garhwal Himalaya India. Forest Ecol Manag. 2010;260:2170-9.

20. Tamooh F, Huxham M, Karachi M, Mencuccini M, Kairo J, Kirui B. Belowground root yield and distribution in natural and replanted mangrove forests at Gazi bay Kenya. Forest Ecol Manag. 2008;256:1290-7.

21. Walcker R, Gandois L, Proisy C, Corenblit D, Mougin É, Laplanche C, Ray R, Fromard F. Control of "blue carbon" storage by mangrove ageing: evidence from a 66-year chronosequence in French Guiana. Global Change Biol. 2018:24:2325-38.

22. Alongi DM. Carbon cycling and storage in mangrove forests. Annu Rev Mar Sci. 2014:6:195-219.

23. Chen L, Zeng X, Tam NF, Lu W, Luo Z, Du X, Wang J. Comparing carbon sequestration and stand structure of monoculture and mixed mangrove plantations of Sonneratia caseolaris and S. apetala in Southern China. Forest Ecol Manag. 2012;284:222-9.

24. He Z, Peng Y, Guan D, Hu Z, Chen Y, Lee SY. Appearance can be deceptive: shrubby native mangrove species contributes more to 
soil carbon sequestration than fast-growing exotic species. Plant Soil. 2018;432:425-36.

25. Komiyama A, Ong JE, Poungparn S. Allometry, biomass, and productivity of mangrove forests: a review. Aquat Bot. 2008;89:128-37.

26. Kristensen E, Bouillon S, Dittmar T, Marchand C. Organic carbon dynamics in mangrove ecosystems: a review. Aquat Bot. 2008;89:201-19.

27. Wang QK, Wang SL, Zhong MC. Ecosystem carbon storage and soil organic carbon stability in pure and mixed stands of Cunninghamia lanceolata and Michelia macclurei. Plant Soil. 2013:370:295-304.

28. You Y, Huang $X$, Zhu H, Liu S, Liang H, Wen Y, Wang H, Cai D, Ye D. Positive interactions between Pinus massoniana and Castanopsis hystrix species in the uneven-aged mixed plantations can produce more ecosystem carbon in subtropical China. Forest Ecol Manag. 2017;410:193-200.

29. Lee SY, Hamilton S, Barbier E, Primavera JH, Lewis RR III. Better restoration policies are needed to conserve mangrove ecosystems. Nature Ecol Evol. 2019;3:870-2

30. Field CD. Mangrove rehabilitation: choice and necessity. Hydrobiologia. 1999;413:47-52

31. Ren H, Jian S, Lu H, Zhang Q, Shen W, Han W, Yin Z, Guo Q. Restoration of mangrove plantations and colonisation by native species in Leizhou bay South China. Ecol Res. 2008;23:401-7.

32. Ren $\mathrm{H}$, Chen $\mathrm{H}, \mathrm{Li} \mathrm{Z}$, Han W. Biomass accumulation and carbon storage of four different aged Sonneratia apetala plantations in Southern China. Plant Soil. 2010;327:279-91.

33. Chen $L$, Wang $W$, Zhang $Y$, Lin $G$. Recent progresses in mangrove conservation, restoration and research in China. J Plant Ecol. 2009;2:45-54.

34. Lu W, Yang S, Chen L, Wang W, Du X, Wang C, Ma Y, Lin G, Lin G. Changes in carbon pool and stand structure of a native subtropical mangrove forest after inter-planting with exotic species Sonneratia apetala. PLoS ONE. 2014;9:000091238.

35. Chen D, Zhang C, Wu J, Zhou L, Lin Y, Fu S. Subtropical plantations are large carbon sinks: evidence from two monoculture plantations in South China. Agr Forest Meteorol. 2011;151:1214-25.

36. Peng Y, Diao J, Zheng M, Guan D, Zhang R, Chen G, Lee SY. Early growth adaptability of four mangrove species under the canopy of an introduced mangrove plantation: implications for restoration. Forest Ecol Manag. 2016:373:179-88.

37. Cintron G, Novelli YS. Methods for studying mangrove structure. In: Snedaker SC, Snedaker JG, editors. The mangrove ecosystem: research methods. France: UNESCO; 1984. p. 91-113.

38. Tam N, Wong YS, Lan C, Chen G. Community structure and standing crop biomass of a mangrove forest in Futian Nature Reserve, Shenzhen China. Hydrobiologia. 1995;295:193-201.

39. Kamal M, Phinn S, Johansen K. Characterizing the spatial structure of mangrove features for optimizing image-based mangrove mapping. Remote Sens-Basel. 2014;6:984-1006.

40. Cordero LDP, Kanninen M. Wood specific gravity and aboveground biomass of Bombacopsis quinata plantations in Costa Rica. Forest Ecol Manag. 2002;165:1-9.

41. Robertson A, Dixon P. Separating live and dead fine roots using colloidal silica: an example from mangrove forests. Plant Soil. 1993;157:151-4.

42. Ha TH, Marchand C, Aimé J, Dang HN, Phan NH, Nguyen XT, Nguyen TKC. Belowground carbon sequestration in a mature planted mangroves (Northern Viet Nam). Forest Ecol Manag. 2018;407:191-9.

43. Schumacher BA. Methods for the determination of total organic carbon (TOC) in soils and sediments. Ecological Risk Assessment Support Center: United States Environmental Protection Agency, Las Vegas; 2002. p. 10.

44. Heiri O, Lotter AF, Lemcke $G$. Loss on ignition as a method for estimating organic and carbonate content in sediments: reproducibility and comparability of results. J Paleolimnol. 2001;25:101-10.
45. Redondo-Brenes A, Montagnini F. Growth, productivity, aboveground biomass, and carbon sequestration of pure and mixed native tree plantations in the Caribbean lowlands of Costa Rica. Forest Ecol Manag. 2006;232:168-78

46. Peng Y, Zheng M, Zheng Z, Wu G, Chen Y, Xu H, Tian G, Peng S, Chen G, Lee SY. Virtual increase or latent loss? A reassessment of mangrove populations and their conservation in Guangdong, southern China. Mar Pollut Bull. 2016;109:691-9.

47. Huxham M, Langat J, Tamooh F, Kennedy H, Mencuccini M, Skov MW, Kairo J. Decomposition of mangrove roots: effects of location, nutrients, species identity and mix in a Kenyan forest Estuarine. Estuar Coast Shelf S. 2010;88:135-42.

48. Bristow M, Vanclay JK, Brooks L, Hunt M. Growth and species interactions of Eucalyptus pellita in a mixed and monoculture plantation in the humid tropics of of north Queensland. Forest Ecol Manag. 2006;233:285-94.

49. Freschet GT, Cornwell WK, Wardle DA, Elumeeva TG, Liu W, Jackson BJ, Onipchenko VG, Soudzilovskaia NA, Tao J, Cornelissen JHC. Linking litter decomposition of above- and below-ground organs to plant-soil feedbacks worldwide. J Ecol. 2013;101:943-52.

50. Liu X, Xiong Y, Liao B. Relative contributions of leaf litter and fine roots to soil organic matter accumulation in mangrove forests. Plant Soil. 2017:421:493-503.

51. McKee KL. Biophysical controls on accretion and elevation change in Caribbean mangrove ecosystems. Estuar Coast Shelf S. 2011;91:475-83.

52. Tomlinson PB. The botany of mangroves. 2nd ed. New York: Cambridge University Press; 2016. p. 273-80. ISBN 978-1-107-08067-6.

53. Middleton B, McKee K. Degradation of mangrove tissues and implications for peat formation in Belizean island forests. J Ecol. 2001;89:818-28.

54. McKee KL, Cahoon DR, Feller IC. Caribbean mangroves adjust to rising sea level through biotic controls on change in soil elevation. Global Ecol Biogeogr. 2007;16:545-56.

55. Ouyang X, Lee SY, Connolly RM. The role of root decomposition in global mangrove and saltmarsh carbon budgets. Earth-Sci Rev. 2017;166:53-63.

56. Silver WL, Miya RK. Global Patterns in Root Decomposition: comparisons of Climate and Litter Quality Effects. Oecologia. 2001;129:407-19.

57. Bosire JO, Dahdouh-Guebas F, Kairo JG, Wartel S, Kazungu J, Wartel S, Kazungu J, Koedam N. Success rates of recruited tree species and their contribution to the structural development of reforested mangrove stands. Mar Ecol Prog Ser. 2006;325:85-91.

58. Liu F, Gao C, Chen M, Li K. Above-and below-ground biomass relationships of Leucaena leucocephala (Lam.) de Wit in different plant stands. PLOS ONE. 2018;13:00000207059.

59. Holmström E, Goude M, Nilsson O, Nordin A, Lundmark T, Nilsson U. Productivity of Scots pine and Norway spruce in central Sweden and competitive release in mixtures of the two species. Forest Ecol Manag. 2018;429:287-93

60. Pretzsch H, Bielak K, Block J, Bruchwald A, Dieler J, Ehrhart HP, Kohnle U, Nagel J, Spellmann H, Zasada H, Zingg H. Productivity of mixed versus pure stands of oak (Quercus petraea (Matt.) Liebl. and Quercus robur L.) and European beech (Fagus sylvatica L.) along an ecological gradient. Eur J Forest Res. 2013;132:263-80.

\section{Publisher's Note}

Springer Nature remains neutral with regard to jurisdictional claims in published maps and institutional affiliations. 